\title{
The Legend of Saint Alan: Larnaudie and Stiegler in the Oversight Committee Room
}

\section{CALUM WATT, SORBONNE NOUVELLE}

Accepted manuscript version of: Calum Watt, 'The Legend of Saint Alan: Larnaudie and Stiegler in the Oversight Committee Room', French Cultural Studies 31:3 (Autumn 2020), 173-184. (C) The Author(s) 2020. DOI: $10.1177 / 0957155819874750$

Link to published article: https://doi.org/10.1177/0957155819874750

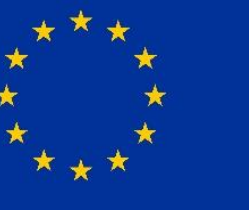

This article is part of a project that has received funding from the European Union's Horizon 2020 research and innovation programme under grant agreement $\mathrm{N}^{\circ} 708042$.

\section{$\underline{\text { Introduction }}$}

This article sets in dialogue two French treatments - one literary, one philosophical - of the October 2008 appearance of Alan Greenspan before the United States House of Representatives Committee on Oversight and Government Reform. Greenspan is the former Chairman of the US Federal Reserve (1987-2006) and generally considered an extremely influential figure in post-war US economic history. However, his reputation was damaged by the 2008 financial crisis, when he was criticised for the unchecked growth of the subprime mortgage bubble occurring under his watch which contributed to the crash. ${ }^{1}$ In the first section of this article I will discuss the chapter dealing with Greenspan in Mathieu Larnaudie's novel about the financial crisis, Les Effondrés (2010). Larnaudie is the author of seven novels and also a director of Éditions Inculte, which specialises in cutting-edge fiction. In the second section, I will analyse the role played by Greenspan in the elaboration of the concept of prolétarisation in the recent interventions of Bernard Stiegler, a philosopher celebrated for his work on technology. Drawing on personal interviews, towards the 
end of the article I develop the counterintuitive notion common to the two writers that Greenspan is a 'saint' of the crisis.

\section{Effondrement}

A récit spanning 24 chapters, Les Effondrés recounts the fate of the key players involved in the 2008 global financial crisis. Although not directly named, they are identifiable by descriptors and clues in the text. Besides Greenspan, they are principally: Angela Merkel; Nicolas Sarkozy; Richard Fuld, Chairman of the investment bank Lehman Brothers, whose bankruptcy marked a climax during the crisis; Bernard Madoff, the financier whose Ponzi scheme was the biggest financial fraud in US history and who is currently serving a 150-year prison sentence; Thierry Magon de La Villehuchet, a French businessman who took his own life after losing his fortune in Madoff's scheme; and Adolf Merckle, a German entrepreneur who also took his own life following losses during the crisis. All, as the title suggests, have been ruined by the crisis. Greenspan and others, Larnaudie remarks in an apparently throwaway comment to which I will return, are the 'saints' of the crisis (Larnaudie 2017, personal communication).

The chapters are relatively short and often comprise a single very long sentence, typically running to several pages. Larnaudie's prose is relentless in the manner in which it relates the very moment of the effondrement. As one critic argues: 'Par la démesure de la phrase, le texte signifie la crise dans l'écriture même, mimant en quelque sorte cette l'économie dématérialisée' (Paugam 2015: 597). The work is highly quotable at the level of vivid individual phrases, but the rhythm of the sentences cannot be evoked without quoting in extenso.

What is typical of the style of the book is given in the syntax of the opening chapter, 'Effondrement'. The first sentence runs to eight pages in length. The sentence opens by evoking, how, after the end of the Cold War, it was supposed that history had ended: 'ce grand récit maintenant passé, relégué, frappé d'obsolescence, qu'ils continueraient d'appeler l'Histoire' (8). The 'triomphateurs' were those who 
'se félicitaient de concert d'avoir su échapper à (débarrasser la planète de) ce fléau nommé "idéologie"” (9). But now, 'soudain, tout s'est effondré' (9). The evocation of the end of history follows only after the book's opening words: 'Et puis un jour, alors même que' (7). This syntactical structure thus sets the putative 'fin de l'Histoire' retrospectively as something merely held in suspension, a sentence waiting to be resumed; the 'fin de l'Histoire' is constructed as the anomaly, rather than the crisis. The first 'alors même que' is followed by three further instances of 'alors que' and then an 'alors même, enfin, que', each opening a clause of about half a page which only closes with a semi-colon before the next 'alors que'. In addition, each clause is packed with parentheses, giving the text a tumbling rhythm. Only at the end of this elaborate grammatical construction do we arrive at the 'soudain, tout s'est effondré', which is followed by a colon opening the next part of the sentence.

But what is it that collapsed? This is the subject of the next part of the sentence, whose activating word is the 'tout' of 'tout s'est effondré'. What collapsed was 'tout ce en quoi ils avaient fait profession de croire, ou plutôt dont ils avaient fait profession d'exploiter, de justifier et de propager partout' (9). It is 'cette étrange foi devenue injonction, devenue horizon providentiel' that is the free market outlook (10). Everything had worked, or seemed to work, 'par la grâce d'un acte de foi continu' (11). In short, then, what collapsed were the ideological underpinnings of the economic system. Thus, most pithily, Larnaudie writes: 'la fin de l'Histoire était finie' (11). For Larnaudie, the financial crisis represents fundamentally an ideological collapse because it required the elite proponents of the free market making the biggest state intervention in the market in the history of the US (the bank 'bailout' packages of 2008). It is not the financial loss for those involved that is most crushing, but the more profound sense that their worldview was flawed. Both Larnaudie's novel and Stiegler's various interventions discussed in the next section should be seen within the wider context of French intellectual responses to the financial crisis, where versions of this idea of an ideological collapse are recurrent (Duménil and Lévy 2011; Lordon 2009; Orléan 2009; Waters 2012: 107-116). The quotations above show how Larnaudie's text employs frequent religious 
metaphors to construct ideology as a secular faith. In a similar vein, we might say that what was shaken was what Joseph Vogl calls oikodicy, 'a theodicy of the economic universe' (16).

The final part of the long first sentence is a series of sketches, each introduced with 'l'on vit', describing traders in London's financial district reacting to the crash, despairing about their presumed imminent dismissal and cursing within the privacy of a toilet cubicle. It is suggested here as elsewhere in Les Effondrés that the primary responses of those actors most directly affected by the crisis are either incredulity or rage at having been 'betrayed' by the system. With this final sequence, the first sentence of the chapter ends and is followed by just two more sentences, each about a quarter of a page in length. Thus, in this final part of the chapter we have a slowing and fragmentation of the rhythm, as if to evoke the final falling pieces of debris of a demolished building (a metaphor Larnaudie deploys later, 2010: 31-32). Just looking at the first sentence of Les Effondrés, we can thus see why the prodigious French translator Claro (2010) has noted the Proustian quality to Larnaudie's sentences.

The phrase 'l'on vit' and variations thereof are found in other parts of the book. In one instance, Larnaudie describes how 'l'on put lire, un matin, dans la presse généraliste' (19) a report about a study into the relation between the length of the fingers of forty-four London traders and their financial success, which found that those with a ring finger longer than their index were likely to be better traders than those without (a ratio supposedly related to increased exposure to testosterone in the womb). Studying the French press of the period, it is likely that the specific article Larnaudie has in mind is from an edition of Le Figaro from January 2009 (Miserey 2009). Larnaudie writes that in the same edition one could find news of the crisis underway:

si, pour les mettre en regard, on les eût agencées en vis-à-vis de cette colonne orpheline et risible, aberrante, égarée dans les pages 'Sciences' (en rejouant, par exemple, une formule de la technique du cut-up [...]), l'on eût pu s'étonner de la continuité incongrue et pourtant significative des fragments de texte ainsi obtenus, de leur cohérence (Larnaudie 2010: 20-21). 
It is as if in the midst of the crisis, homo economicus was grasping at straws for new evidence of his ordained nature. Closing the second chapter on an absurd note, we read that the blame should perhaps have fallen not on those running the system, but on those whose index fingers were longer than their ring fingers (21).

With this reference to the cut-up technique, associated notably with William S. Burroughs, Larnaudie inscribes in the text its origins in the press reporting of the crisis. Les Effondrés plays frequently on the tension between recounted fact and imagined psychological detail. Larnaudie has described the thrill of writing the piece 'sur le vif' as the events were unfolding (he wrote the book in 2008-2009 and it was published in spring 2010). Larnaudie was thus quick to recognise the significance of the crash. The choice of long sentences allowed him to capture the flow of the story as it emerged, offering a 'grande plasticité' in which the sentence develops organically (2017, personal communication).

The chapter on Greenspan, 'Les Reniements du Maestro', is the core of the book and the Congressional hearing it describes was the inspiration for the book. This hearing took place on 23 October 2008, when Greenspan was summoned to the Committee on Oversight and Government Reform to ‘expliciter sa pensée dans un langage limpide’ (Larnaudie 2010: 37). Before Congress, Greenspan appears like a mythical figure: the committee members are conscious of 'la légendaire fresque de son existence et de son œuvre', themselves involved in 'le culte des valeurs et des idées dont il était la plus brillante incarnation' (37). Greenspan is referred to by his soubriquet 'le Maestro', a moniker which is increasingly put under strain as the text goes on. With an ironically hagiographical rhetoric, Larnaudie sketches Greenspan's career:

en sa qualité d'apôtre parfait et de prosélyte convaincant de l'évangélisme libéral, propulsé à la tête de la Réserve fédérale, y mener une politique opiniâtre et réputée pragmatique, ainsi qu'il s'en était lui-même toujours targué [...], couronnée d'un succès amplement célébré, encensée pour la manière dont elle avait su contrer les conjonctures défavorables et accompagner la prospérité spectaculaire que l'avènement de la révolution industrielle des nouvelles technologies avait suscitée; cet homme, enfin, qui avait quitté sa place tandis que commençaient de poindre les frémissements annonciateurs 
de la catastrophe qu'il avait largement contribué à provoquer: et c'était cela, précisément, sa contribution, la part qui lui incombait, son désastreux héritage, ou plutôt son legs devenu l'envers désastreux de sa légende dorée [...] qu'il était du devoir de ses auditeurs, tous plus jeunes que lui, incrédules, désemparés non moins que lui sans doute, et investis d'une haute mission de justice, d'évaluer et de juger là. (39-40).

Here we see how the humbling of Greenspan is essentially bound up with the fact that he is regarded as the incarnation of the ideology, couched in religious terms as a kind of failed saint (later this 'sorte de pape pour notre temps' [34] will be described as apostatised and as 'défroqué' [47]). As head of the Federal Reserve, his success was the success of the whole American economy. Yet he is also the one partly responsible for the crisis - his is a 'désastreux héritage'.

The whole eight-page chapter dealing with Greenspan consists of only three very long sentences, each of which contains very long parentheses. The scene is described in surreal detail. In one parenthesis we are treated to a microscopic description of the face of the committee Chairman, who:

se penchait sur son pupitre chaque fois qu'il prenait la parole, qu'il posait une question ou demandait une précision, jusqu'à presque coller ses lèvres à la petite boule de mousse noire de son micro, puis se reculait, quand il attendait les réponses du Maestro, pour s'appuyer au dossier de sa chaise en fronçant, sous les plis attentifs, concentrés, de son grand front dégarni, ses sourcils broussailleux, lourds, ou en avançant, dans une mimique nerveuse, sous la barre de moustaches grises en surplomb de sa bouche, les grandes dents écartées de rongeur qui conféraient l'aspect outré et élastique d'une caricature de presse ou d'un personnage de cartoon à ce sénateur affublé par ailleurs d'un nom saugrenu, résultant de l'apposition des morts anglais qui signifient 'cire' et 'homme', et que l'on eût donc pu traduire par 'l'homme-cire', ou 'l'homme de cire', nom qui avec la laideur exceptionnelle et la grande malléabilité de ses expressions contrastait résolument, à moins qu'on ne pût penser que l'ensemble de sa tête était effectivement taillé dans une boule de cire qui, en fonction des variations de température, se déformait, se liquéfiait ou durcissait (40-41). 
This is Henry A. Waxman, a Democrat Representative from California. Here the diminutive descriptions of the senator's features point to the impotence of the 'oversight' functions of Congress in contrast to the power of the 'Maestro' on whose every word the assembled company hangs. As well as showing how Larnaudie gives crossword-like clues as to his real-life references, the humorous wordplay on the senator's name dissolves the reality of the proceedings in an oneiric fashion, much as does the reverie of the melting of his waxen head. Larnaudie's text zooms in on hallucinatory, hyperreal details to evoke a real-life figure, the prose underscoring the unreality of the situation.

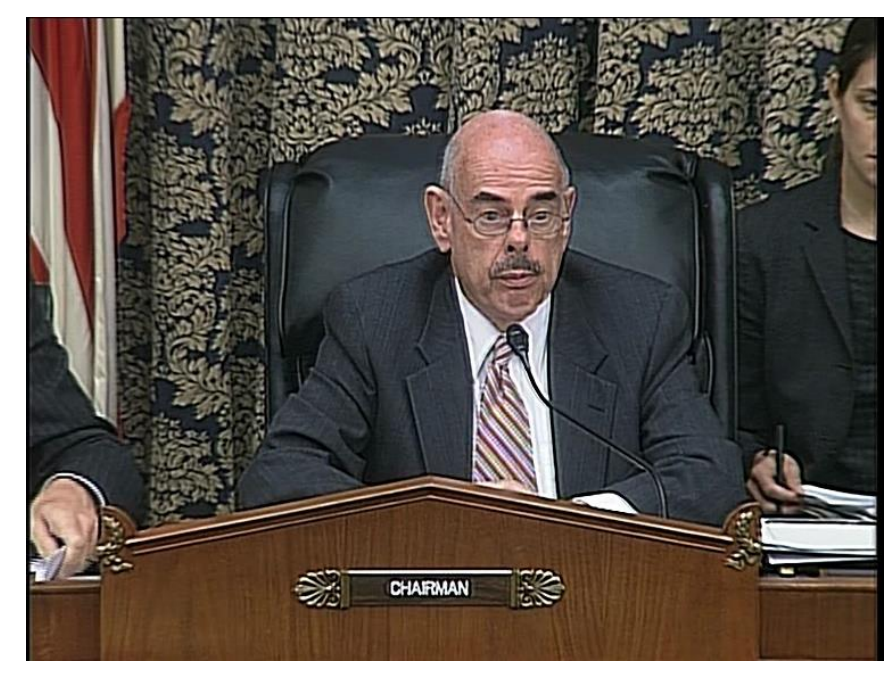

FIGURE 1: Henry Waxman

Larnaudie's text was composed from repeated viewings of the hearing video and from adapting press reports. I want to suggest that what is particularly important here is how the writer treats the footage and transcript of the hearing - documentary legal evidence given under oath - as raw materials for a literary text. The media is generally a key subject and resource for Larnaudie's fiction: the main character of his 2012 novel Acharnement is a political speech writer, while another novel (2015) is loosely inspired by the life of the actress Frances Farmer. When put to him that the chapter constitutes an ekphrasis of the hearing and press documents, Larnaudie comments:

Oui, exactement. Mais en plus le mot est juste parce que quand je travaillais sur ces documents [...] j'ai fait une sorte d'ekphrasis d'image et de représentation contemporaine. Ce n'est pas un tableau 
classique, ce n'est pas une sculpture antique, c'est une vidéo d'un dirigeant de la Fed devant le congrès [...] L'idée c'était comme dans une ekphrasis, la description rigoureuse doit déployer, déplier les significations contenues dans l'image. Là c'est un peu que j'ai fait (2017, personal communication).

Larnaudie's work thus offers one example of the way an American media-political event at the heart of the global financial crisis finds its way into a French cultural representation of that crisis, the literary text becoming an intermedial reflection on the way the crisis crystallised as image. While this operation could be considered ekphrastic, the close description of the footage and the unpacking of the image might also suggest a film sequence analysis, an analysis that Larnaudie turns into literature. Thus in another context, Larnaudie remarks: 'La crise était pour moi le nom de l'apparition des corps, des gestes, des fragments de discours, qui composaient une nouvelle scène où j'ai eu envie de faire circuler un récit'; what he was seeking was the 'l'expérience sensible' of events (Goude 2010). Like Waxman, Greenspan is also described in close detail:

aussi, tandis que son visage aux lèvres épaisses et, lorsqu'il parlait, humides, presque retroussées, aux larges lunettes rondes grossissant de petits yeux myopes et mobiles rétractés dans leurs cavités et animés par des paupières papillonnantes, marquait sa volonté de se rendre parfaitement intelligible, s'efforçait de revêtir la juste formule intermédiaire entre le sourire affable et la gravité circonstanciée - entre la stupeur et la sérénité -, l'entendit-on reconnaître, médusé lui-même par les paroles qu'il articulait, que les institutions économiques et celle qu'il avait dirigée en premier lieu avaient traversé 'une période de sous-estimation des risques' (41-42).

There is an effect of bathos in the switch of register from surreal micro-detail to euphemistic economic jargon of 'risques'. We get a clear sense here of how Greenspan is 'effondré' - he is almost in a stupor, fallen from his legendary status and revealed to be a mortal 'myopic' man. Again, what is striking is how the older religious language of saints and legends is contained in the description of details of modern media image. 


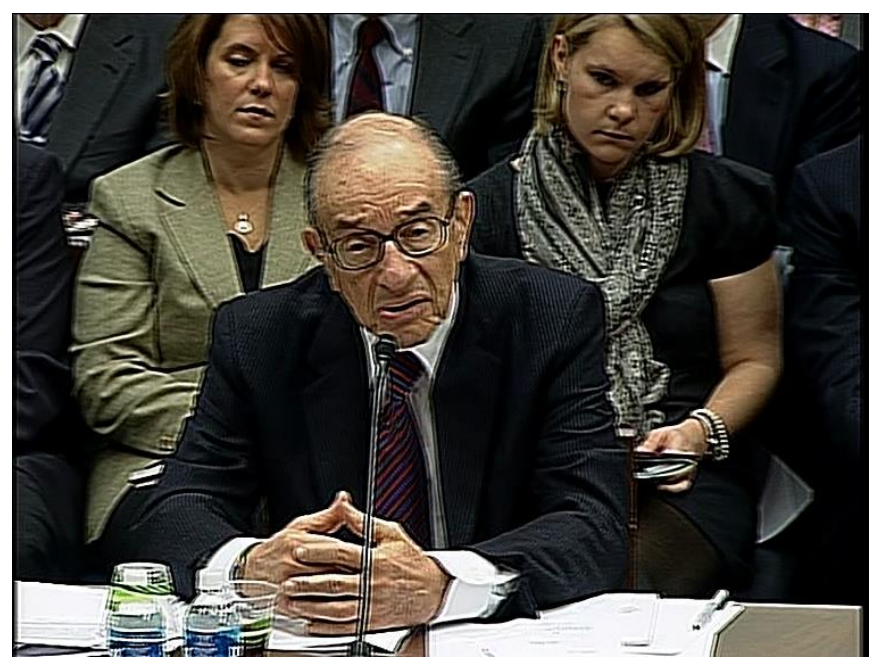

FIGURE 2: Alan Greenspan testifies before Congress, 23 October 2008

In terms of the wider significance of this hearing within the context of the crisis, the crucial concession from Greenspan's testimony is quoted in Larnaudie's text (in French), that he had 'made a mistake in presuming that the self-interests of organizations, specifically banks, were such that they were best capable of protecting their own shareholders and their equity in the firms' (42; Committee 2008: 45). Larnaudie recounts the moment when Waxman asks whether there was a flaw in Greenspan's ideology. Quoted below is the key exchange from the official transcript:

Mr. GREENSPAN. Well, remember, though, whether or not ideology is, [sic] is a conceptual framework with the way people deal with reality. Everyone has one. You have to. To exist, you need an ideology. The question is, whether it exists is accurate or not. What I am saying to you is, yes, I found a flaw, I don't know how significant or permanent it is, but I have been very distressed by that fact. But if I may, may I just finish an answer to the question -

Chairman WAXMAN. You found a flaw?

Mr. GREENSPAN. I found a flaw in the model that I perceived is the critical functioning structure that defines how the world works, so to speak. 
Chairman WAXMAN. In other words, you found that your view of the world, your ideology, was not right, it was not working.

Mr. GREENSPAN. Precisely. That's precisely the reason I was shocked, because I had been going for 40 years or more with very considerable evidence that it was working exceptionally well. (Committee 2008: 46).

Recounting this exchange, Larnaudie adds imagined details absent from the transcript to describe the feelings of those in the hall as the master responds:

sans doute furent-ils, à l'instant précis où ces mots franchirent ses lèvres, nombreux ceux dont le sang se glaça, nombreux ceux qui guettèrent autour d'eux, sur d'autres visages, les réactions les assurant qu'ils n'avaient pas été les victimes d'un problème acoustique, que la scène pour ainsi dire surréaliste, impensable à laquelle ils assistaient avait bel et bien lieu (42).

Larnaudie underlines the importance of the word 'idéologie' in the exchange:

le fait qu'à ce moment, il n'eût pas reculé devant le mot 'idéologie', [...] équivalait rigoureusement à confesser soudain que sa foi béate dans le libre marché avait été anéantie, que sa confiance inconditionnelle en l'invincibilité du système était désormais caduque, que ses conceptions de la vie des hommes et de la nature, de l'ordre leur convenant, se révélaient tout simplement fausses, erronées, inadéquates au réel (43).

While the moment when he agreed to discuss the meaning of the word 'ideology' has been read by some as a serious error by Greenspan, his biographer defends him on this point: 'It was an unremarkable observation. Of course, all ideologies had flaws; the fact that Greenspan had acknowledged his went only to show his pragmatism' (Mallaby 2016: 667-68). Yet it is as if merely acknowledging the relevance of the concept of ideology itself constitutes a 'confession' that he was ideologically driven. Ideology is not to be directly referred to, for that is to step outside of it, whose purpose is to encompass and regulate discourse. It wants to set the limits on the speech of others, rather than be revealed as itself a limit. What is inventive 
about Larnaudie's technique of description or ekphrasis of the media image is that it allows him to pinpoint, replay and textually analyse the precise moment when the shock occurs, when ideology is revealed as a limit.

Larnaudie remarks that Greenspan was 'sincère dans son effarement'. He was 'accusé', even though he was not on trial as such. The result was that 'il plaide sa cause et il plaide coupable'. Given that in subsequent interventions Greenspan would return to a pro-market position, for Larnaudie:

Ça prouve qu'il est effectivement allé sans doute un peu trop loin par rapport à ce qu'il aurait pu se contenter de dire. Peut-être qu'il l'a regretté. Mais justement c'est ça qui est intéressant. C'est que parce qu'il est allé trop loin qu'il est sans doute allé dans le vrai. [...] Sans trop le dissimuler, sans trop le déguiser, sans trop atténuer les choses (Larnaudie 2017, personal communication).

Towards the close of the chapter, Larnaudie writes that:

lorsqu'il se tut, $[\ldots]$ dans les effluves de transpiration, d'eaux de toilette et de bois suintant qui circulaient dans la salle, au lieu du tumulte usuel et immédiat par quoi les auditeurs reviennent à euxmêmes et à leurs préoccupations, un silence gêné continua de planer pendant quelques minutes, et le Maestro repenti se retourna pour parcourir l'assemblée du regard, adresser quelques signes de tête à l'intention de certains, peut-être pour évaluer les effets de la soudaine et désarçonnante transvaluation qui venait de s'opérer (43-44).

Amidst the imagined olfactory details, crucial here is the notion that what took place was a 'transvaluation', a notion I will develop in the next section. Zooming out from Greenspan, Larnaudie reinscribes his French position in relation to this event by alluding to the immediate radio reaction of Alain Minc (not directly named) as one of those who failed to grasp 'l'ampleur du phénomène' (44) that had taken place, and to deny its significance. ${ }^{2}$ The final lines of the chapter lay bare the material source of the text, evoking how the words of Greenspan instantly became a media event as people received, 'transférés par e-mail, les liens 
vers les vidéos mises en ligne présentant les séquences les plus significatives du témoignange du Maesto’ (44-45), the event thus rippling out into the wider culture.

\section{Prolétarisation}

Like Larnaudie, the philosopher Bernard Stiegler argues that we have to be careful when interpreting Greenspan's remarks because at the same time as they constitute a 'un aveu', they are also a 'un système de défense': 'il est obligé d'avouer pour pouvoir se défendre' (Stiegler 2017, personal communication). Like Larnaudie, Stiegler was quick to recognise the significance of the Greenspan hearing, it becoming for Stiegler a resource for the development of a philosophical concept. Stiegler has alluded frequently to Greenspan's appearance on Capitol Hill as a privileged example of what he theorises as 'prolétarisation', a concept distinct from, but which nonetheless resonates with, Larnaudie's description of a collapsing ideology. ${ }^{3}$ According to Stiegler, in this moment Greenspan had lost all economic 'savoir'. Of course, he still had a salary of millions of dollars, Stiegler says, but he had no more knowledge:

ce salarié avait lui aussi perdu son travail, car un travail est toujours un savoir, et réciproquement, mettre en œuvre un savoir, c'est toujours travailler [...] Greenspan, désœuvré, n'avait plus qu'un emploi: c'était un employé de la bureaucratie financière mondiale, prolétarisé comme le sont tous les employés (2015a: 33).

Stiegler's play on the senses of work and unworking offers a different sense of Greenspan's effondrement, of how he appeared 'comme un prolétaire d'un nouveau genre' (2015a: 33).

What is 'prolétarisation'? Ars Industrialis, the activist group with which Stiegler is associated, offer a definition (2013): 'La prolétarisation est, d'une manière générale, ce qui consiste à priver un sujet (producteur, consommateur, concepteur) de ses savoirs (savoir-faire, savoir-vivre, savoir concevoir et théoriser).' Classically, this is due to technology. Here Stiegler's reading of the Greenspan testimony plugs into his broader philosophical project, notably as articulated in the La Technique et le temps series (1994- 
), according to which the exteriorization of memory in writing constitutes a loss of memory and knowledge. For Stiegler, this is now our experience in every aspect of our existence, especially our feeling of powerlessness in the face of the vastness of human memory made available by digital networks. While we may have been accustomed to think of the proletariat as those rendered the appendage of a machine and who have lost their savoir-faire, now it is consumers who are deprived of knowledge by service industries. What the 2008 crisis brought to light was that now it is those who run the system - 'les concepteurs et les décideurs' - who are proletarianised as a result of their reliance on trading software, whose risk models evidently failed (Ars Industrialis 2013). Stiegler refers to Greenspan because he is 'un symptôme particulièrement symbolique de cette situation' (Stiegler 2017, personal communication). As Stiegler puts it in a key statement of his outlook:

La situation contemporaine de prolétarisation généralisée s'est planétairement avérée constituer en 2008 une économie de l'incurie, une déséconomie généralisée, installant une dissociété intrinsèquement irresponsable parce que systématiquement fondée sur la dilution de responsabilité, c'est-à-dire sur une bêtise systémique, anti-noétique, qui est aussi une infidélité systémique du consommateur aussi bien que du spéculateur, qui jettent leurs objets, et qui est en cela génératrice d'une défiance structurelle, destructrice de ses propres conditions de possibilité: elle mène au gaspillage énergétique et à l'épuisement de toutes les formes d'énergie - énergies de combustion, c'est-à-dire de subsistance, et énergies libidinales, c'est-à-dire d'existence. (2015b: 362-63).

In the above quotation, we can see how Stiegler is unusual even among severe critics of the financial crisis in seeing the profundity of its causes and consequences. This is why Stiegler disarmingly avers that 'la crise n'est pas financière' (Stiegler 2017, personal communication). What we call the financial crisis is really the symptom or forewarning of a more serious crisis of 'l'insolvabilité économique générale', an economic crisis in the widest sense of the word 'economic', thus having social, moral and even existential consequences and which will become more dangerous as automatization in the world of work continues (2016: 256). Stiegler predicts a drastic increase in unemployment, in France as well as globally, which will 
contribute to the increasing entropy or disorder in the world today (2015b: 15). Within this context Stiegler asks whether another future is possible. For him, the increased free time created by automation must be used to rethink the meaning of work and value in general. Stiegler considers policy ideas such as the universal basic income, but his prescription is for a broader metaphysical change, a 'transvaluation' of economic and moral values whereby we try to reverse the chaos and toxic elements in the world (2015b: 25). We should thus cultivate knowledge and the individual through practices of 'déprolétarisation' by which we learn new techniques, recover lost skills, take up our responsibilities toward others, and generally put things back in order. In his most recent articulation of this idea (2018), Stiegler argues for the need for 'pænser', forging together penser with the Old French word panser, meaning to bandage, to tend (a wound) or more generally to care for, thus suggesting 'to think care-fully' or 'to think and care'. Stiegler's thinking on the questions of knowledge and prolétarisation should be seen within the context of other adjacent concepts in contemporary French thought, such as 'le capitalisme cognitif' and 'l'économie pollen', as elaborated by Moulier-Boutang $(2007 ; 2010)$ and the Multitudes group, notions about which Stiegler is ambivalent despite their apparent proximity to his thought (see 2009 and 2015b: 368-74, 389).

In his latest book, Stiegler attributes the failure to respond adequately to the crisis by states and institutions like the European Central Bank to the complete disappearance of critical political-economic thought, in France and globally, in the face of the prevailing ideology, which is now in comprehensive crisis (2018: 172-73). Here Stiegler's analysis connects with Larnaudie's: prolétarisation is both a cause and consequence of submersion in ideology. This conditions the 'immense régression' (91) of recent decades, intensified by the rapid technological change and whose culmination is the election of Donald Trump and the so-called post-truth era. In many stark formulations in his previous book, Dans la disruption, Stiegler situates the financial crisis within a contemporary moment marked by an 'accumulation des calamités' (2016: 28), 'une démoralisation généralisée' (108) and 'un devenir fou planétaire' (254). While Larnaudie offers us an extreme close-up of the very moment of Greenspan's ideological effondrement, Stiegler sets it against a vast and catastrophic horizon in which metaphysical change is urgently needed. 
The Greenspan hearing nonetheless does offer for Stiegler a symbol of the transvaluation of values and the new political economy of déprolétarisation that remains to be accomplished. As Larnaudie shows in Les Effondrés, it is precisely in conceding the word 'idéologie' as a term of argument that the terrain of ideology is itself revealed, and this is the first step in transvaluation. For Stiegler, ideology must be understood in the sense of that which surrounds us and that we do not see, in the sense that a fish does not see the water (2017, personal communication). ${ }^{4}$ Specifically, it should be understood as technology, as the way the human mind and body are produced by technology. Ideology is an illusion which inverses cause and effect, Stiegler says, allowing us to think it is the mind that creates technology, rather than the other way around. Thus what Greenspan 'confesses' is that he had not seen, until the crisis, that he had inverted cause and effect: he thought he was in control of the algorithms at work in the financial system, but in fact it was the other way around (Stiegler 2017, personal communication). While the concept of prolétarisation may at first glance give us to think that Stiegler constructs the financial crisis as a question of technology rather than ideology, in fact the Greenspan testimony illustrates how these are mutually implicated: it is ideology that both causes the loss of savoir in technology and blinds one to this state of affairs. Thus Greenspan's transvaluation is to have stepped outside of his ideology and recognised himself as proletarianised. Stiegler claims it must have been an ordeal for Greenspan to see the whole system that he had created collapse. Exactly like Larnaudie, Stiegler comments that while Greenspan was not on trial as such during his hearing, he was 'mis en cause'. This, says Stiegler, gave him a new and lucid perspective.

Larnaudie's quasi-religious reading of Greenspan as a 'saint of the crisis' finds an unexpected parallel when Stiegler compares Greenspan to the legend of Saint Julien l'Hospitalier, best known in the dreamlike retelling by Gustave Flaubert in his Trois Contes (1877) (Stiegler 2017, personal communication). ${ }^{5} \mathrm{~A}$ brief recap: when Julien is born, his parents receive visions telling them that their son will become a saint. He grows to be a bloodthirsty hunter of animals. One day, however, Julien encounters a deer which prophesies that he will kill his parents. Thenceforth, Julien abandons hunting and leaves his castle, for fear of accomplishing the prophecy. He becomes a famous soldier and takes an emperor's 
daughter for a wife. He lives in a palace and no longer wages war. Yet, one night temptation takes him, and he goes out to hunt. At the same time, two elderly beggars arrive, who are in fact Julien's parents, who have been travelling the world for years looking for their son. Julien's wife puts them in the marital bed. Out on the hunt, Julien finds himself thwarted at every turn, can no longer kill and returns home in a rage. Finding the couple in bed, he believes he sees a man in bed with his wife and murders them both - thus realising the prophecy. Julien becomes a wandering outcast. The tale ends when a leper calls to Julien, and Julien cares for and embraces him before ascending into heaven.

For Stiegler, the saint's life is about a conversion. He believes that Greenspan experienced a conversion: not a religious conversion, but a phenomenological one. As in Larnaudie's text, it was a transvaluation by which Greenspan saw beyond his ideology. He was forced to shed his illusions and, for Stiegler, we must generalise this process and make others too lose their illusions and recognise themselves as prolétarisés. For Stiegler, the way out of the present impasse will not be by through Christianity, but rather a new critique of political economy. Although Greenspan has not become a wandering mendicant, and even if he later downplayed his 'conversion', it is in the sense common to both Larnaudie and Stiegler that he is the one who, before the world's media, underwent an ideological transvaluation that he is a 'saint' of the crisis. ${ }^{6}$

\section{Conclusion}

Larnaudie remarks that what he tried to make palpable in Les Effondrés was 'la naissance d'une incertitude' (2017, personal communication). It was ideology that constructed the putative certainty of the 'end of history'. Larnaudie and Stiegler represent two French interpretations within a much wider debate in the West on the significance and impact of the 2008 global financial crisis for the postwar geopolitical order, which now undergoing mutation. This looks different in every country, but, as historians argue, everywhere the future looks deeply uncertain. ${ }^{7}$ The religious rhetoric deployed by the two writers when describing 
Greenspan, whose hearing was framed in the most modern, digital conditions, points to the untimely or anachronistic nature of that ideology or faith that collapsed in 2008. The value of Larnaudie and Stiegler's texts is their return to the critical moment - this transvaluation - when the new uncertainty was born under the sign of Saint Alan. It is the way in which both, recounting the crisis in their different ways, force us, like him, to shed our illusions. 


\section{$\underline{\text { References }}$}

Ars Industrialis (2013) Vocabulaire. Available at: http://arsindustrialis.org/vocabulaire (accessed 28 March 2019).

Chi-ah Lyu, C (2011) Flaubert's Proposition. French Forum, 36:2-3: 41-60.

Claro (2010) A la recherche du tant perdu. In Toward Grace blog. Available at: www.towardgrace.blogspot.fr/2010/04/la-recherche-du-tant-perdu.html (accessed 29 July 2018).

Committee on Oversight and Government Reform (2008) The Financial Crisis and the Role of Federal Regulators: Hearing Before the Committee on Oversight and Government Reform. Available at: www.gpo.gov/fdsys/pkg/CHRG-110hhrg55764/pdf/CHRG-110hhrg55764.pdf (accessed 28 March 2019).

Duménil G and Lévy D (2011) The Crisis of Neoliberalism. Massachusetts: Harvard University Press.

Flaubert G (1973) Trois Contes. Paris: Gallimard.

Goude J (2010) Pandémie spéculative. Le Matricule des anges 114: 34-35.

Larnaudie M (2010) Les Effondrés. Arles: Actes Sud.

Larnaudie M (2012) Acharnement. Arles: Actes Sud.

Larnaudie M (2015) Notre désir est sans remède. Arles: Actes Sud.

Lordon F (2009) La Crise de trop: Reconstruction d'un monde failli. Paris: Fayard.

Mallaby S (2016) The Man Who Knew: The Life \& Times of Alan Greenspan. London: Penguin.

Marx K and Engels F (1978) The German Ideology. In: Tucker RC (ed) The Marx-Engels Reader. New York: W. W. Norton \& Company, pp.146-200.

Miserey Y (2009) L’annulaire long, signe distinctif du trader. Le Figaro, January 13, 2009. 
Moulier-Boutang Y (2007) Le Capitalisme cognitif: La Nouvelle Grande Transformation. Paris: Éditions Amsterdam.

Moulier-Boutang Y (2010) L'Abeille et l'économiste. Paris: Carnets Nord.

Orléan A (2009) De l'euphorie à la panique: Penser la crise financière. Paris: Éditions Rue d’Ulm.

Palermo di Stefano RM (2017) Julien. In: Le Calvez E (ed) Dictionnaire Gustave Flaubert. Paris: Éditions Garnier, pp.628-29.

Paugam G (2015) Mathieu Larnaudie: Une écriture de (la) crise. Contemporary French and Francophone Studies 19:5: 593-601.

Snyder T (2018) The Road to Unfreedom: Russia, Europe, America. New York: Tim Duggan Books.

Stiegler B (2009) Pour une nouvelle critique de l'économie politique. Paris: Galilée.

Stiegler B (2015a) L'Emploi est mort, vive le travail! Paris: Mille et une nuits.

Stiegler B (2015b) La Société automatique 1. L’Avenir du travail. Paris: Fayard.

Stiegler B (2016) Dans la disruption: Comment ne pas devenir fou? Paris: Les Liens qui libèrent.

Stiegler B (2017a) Critique de la raison impure: Entretien avec Bernard Stiegler. Esprit (Mars-Avril 2017): $118-29$.

Stiegler B (2017b) Entretien avec Bernard Stiegler. Rue Descartes. 91:1: 119-40.

Stiegler B (2017c) Il faut réinventer le travail. Politis, hors-série 66: 4-6.

Stiegler B (2018) Qu'appelle-t-on panser? 1. L'Immense régression. Paris: Les Liens qui libèrent.

Tooze A (2018) Crashed: How a Decade of Financial Crises Changed the World. London: Allen Lane.

Vogl J (2015) The Specter of Capital. Stanford, California: Stanford University Press. 
Waters S (2012) Between Republic and Market: Globalization and Identity in Contemporary France. London: Continuum.

\footnotetext{
${ }^{1}$ For a sympathetic account of Greenspan's response to the crisis, see Mallaby 2016: 648-71. For a general history of the crisis, see Tooze 2018.

${ }^{2}$ On Minc's role as an economist regularly brought out in the media to offer an orthodox line, and in particular as one who failed to foresee the crisis, see the documentary film Les Nouveaux Chiens de garde (Yannick Kergoat and Gilles Balbastre, 2012).

${ }^{3}$ Stiegler has engaged with the crisis from its immediate aftermath (2009) to the present. In this section I discuss Stiegler's allusions to Greenspan in his major texts since the crisis. It is worth adding that in recent interviews Stiegler continues to repeatedly refer to the Greenspan testimony $(2017 \mathrm{a}, 125 ; 2017 \mathrm{~b}, 125$; 2017c, 6).

${ }^{4}$ Stiegler is thinking here of Marx and Engels 1978.

${ }^{5}$ For a discussion of sources, autobiographical elements and major readings of the tale, see Palermo di Stefano 2017.

${ }^{6}$ Both Flaubert's Julien and 'Les Reniements du Maestro' contain ironic hagiographical elements. On the tension between hagiography and Flaubert's modernist sensibility, see Chi-ah Lyu 2011.

${ }^{7}$ Alongside Tooze 2018, see for example Snyder 2018.
} 